\title{
No quilombo, uma flor?
}

\section{Robert Daibert Junior}

SILVA, Eduardo. As camélias do Leblon e a abolição da escravatura: uma investigação de história cultural. São Paulo: Companhia das Letras, 2003, $136 \mathrm{p}$.

O significado de uma inocente flor levou Eduardo Silva a descortinar o que considerou "um novo paradigma de resistência ao sistema escravista". Ao desvendar o significado simbólico das camélias, o historiador propõe-se investigar as "ligações secretas" entre a articulação política empreendida pela elite e o movimento social negro.

Entre estes segmentos sociais, as camélias aparecem como um importante veículo de comunicação simbólica. Por meio delas, os adeptos do abolicionismo identificavamse numa espécie de código secreto. O cultivo de camélias nos jardins domésticos, bem como seu uso na lapela do paletó ou no vestido, tornouse, no final do século XIX, uma verdadeira confissão de fé abolicionista.

Nos primeiros capítulos do livro, tomamos conhecimento do quilombo abolicionista. Diferente de nosso velho conhecido quilombo-rompimento, esta modalidade caracterizava-se por ser dirigida por um novo tipo de liderança: em vez de grandes e ousados guerreiros, deparamo-nos com cidadáos conhecidos e bem articulados politicamente que promoviam a intermediação entre os fugitivos e a sociedade que os acolhia e protegia.

O quilombo do Leblon, objeto de sua pesquisa, era sediado em uma chácara de propriedade do português José de Seixas Magalhães, um próspero fabricante e comerciante de malas da Rua do Ouvidor que, além de exportar seus produtos, investia em terras na então bucólica zona sul do Rio de Janeiro. Em ponto estratégico, por seu difícil acesso, Seixas cultivava camélias com o auxílio de seus refugiados e realizava reuniōes abolicionistas com a presença de José do Patrocínio, Joaquim Nabuco, João Clapp, entre outros. Seixas contava com a cumplicidade dos ilustres membros da Confederação Abolicionista, orga- 
nização que contribuía financeiramente para manutenção de seu quilombo. Além disso, guardava certa proximidade com a própria Princesa Isabel que, certa vez, intercedeu junto ao imperador no sentido de evitar uma iminente invasão policial em sua chácara-quilombo.

No terceiro capítulo, Eduardo Silva nos revela a ousadia da Princesa ao aderir, abertamente, ao movimento abolicionista, promovendo festas para arrecadação de fundos para emancipação dos escravizados e mesmo recolhendo escravos fugidos no próprio palácio de Petrópolis. Com o auxílio de importantes damas da Corte, participava de um esquema de fugas naquela cidade, estabelecendo ligaçôes com o altocomando da Confederação no Rio nas quais tinha André Rebouças como intermediário.

As camélias permeavam as relaçóes entre os abolicionistas e dos mesmos com o palácio. Seixas, o chefe do quilombo do Leblon, fornecia as flores que ornamentavam o gabinete de trabalho da Princesa, sua capela e seus vestidos. Outro ponto destacado no livro (e já explicitado pelos biógrafos de Isabel) diz respeito à promoção, em Petrópolis, das famosas "batalhas de flores" nas quais a princesa angariava fundos para compra de alforrias. No entanto, Eduardo Silva lamentavelmente não explora o significado do uso e da apropriação desta espécie de festa carnavalesca - amplamente difundida na Europa - para fins abolicionistas, no Brasil. A doação da Rosa de Ouro feita pelo papa Leão XIII à Princesa tampouco é explorada.

Sem dúvida, o quilombo do Leblon tornou-se o centro simbólico do movimento abolicionista tal qual era pensado pelos membros da Confederação na Corte. Ou seja, expressava a defesa de uma libertação imediata e sem indenização. Desta forma, as camélias de Seixas tornaram-se peças indispensáveis em todas as manifestaçōes favoráveis a este tipo de resolução. $\mathrm{O}$ simbolismo das camélias também aparecia constantemente nas caricaturas que circulavam na Revista Ilustrada dirigida porÂngelo Agostini -, reproduzidas ao longo do livro.

No quarto capítulo, Eduardo Silva analisa a relação de Rui Barbosa com seu jardim e o significado da localização das camélias naquele espaço, esboçando, ao final, argumentos que procuram demonstrar que aquelas flores da liberdade foram ofertadas por Seixas ao jurista. Porém, neste aspecto, as evidências são precárias, embora não improváveis. 
Interessante notar que as camélias, ainda hoje, permanecem florindo o jardim da Casa de Rui Barbosa em Botafogo.

Nos capítulos 5 e 6, vemos a percepção de Rui quanto à ilegalidade da escravidão. A base de seu abolicionismo estava relacionada à interpretação de que a fraude e o abandono da lei de 1831, que proibia a entrada de africanos como escravos no Brasil, corrompia todo o sistema. Logo, a escravidão era um roubo e, por isso, era legítimo apoiar as fugas. Por ser ilegal, era preciso aplicar a própria lei de 1831 que previa a libertação imediata de todos os africanos traficados para o Brasil após aquela data, bem como a de seus descendentes. Neste sentido, o apoio aos quilombos não constituía crime, e sim o restabelecimento pleno da lei e da justiça.

No sétimo capítulo, Silva reconstrói as ligaçóes de amizade entre o português Seixas, chefe do quilombo do Leblon, o intelectual Rui Barbosa e os ilustres membros da Confederação Abolicionista. O que o autor parece querer enfatizar em todo este capítulo é que o sentimento de liberdade podia unir pessoas tão diferentes como um preeminente membro da elite política e intelectual brasileira e um imigrante português voltado para negociações de imóveis e terras, exportação e comércio de malas. Ligação que, segundo Silva, apontaria para o caráter radical do abolicionismo de Rui.

O oitavo e último capítulo apresenta um delicioso convite ao leitor: com o auxílio de uma planta da configuração urbana atual da zona sul do Rio de Janeiro e, com um lápis na mão, somos transportados ao século XIX por meio da reconstituição das trilhas e dos percursos que levavam abolicionistas e escravos ao "underground" abolicionista do Leblon. Um exercício interativo que nos faz "pisar" naquelas terras então longínquas e pouco habitadas.

Não há dúvida de que o livro, em seus oito capítulos e seis apêndices contendo alguns dos documentos-chave da análise proposta, traz uma importante contribuição à historiografia da abolição. Ao lançar luz sobre este espaço de resistência pouco conhecido, Eduardo Silva amplia o nosso conhecimento sobre as diferentes facetas do processo final de extinção da escravidão no Brasil. Chegamos a sentir o cheiro das camélias partindo das plantações de Seixas em sua Chácara no Leblon, perfumando todo o Palácio das Laranjeiras (residência da Prin- 
cesa Isabel no Rio), exalando pelas ruas da Corte e nas redaçôes dos jornais, atingindo os diversos quilombos abolicionistas espalhados pela cidade e chegando até Petrópolis. Trata-se, sem dúvida, de uma narrativa intrigante e envolvente na qual somos conduzidos por meio de uma leitura agradável e de fácil acesso, o que a torna recomendável ao público leigo em geral.

O autor ressalta, no entanto, que os resultados apresentados no livro são provisórios, uma vez que a pesquisa faz parte de um projeto em andamento, dedicado ao estudo das festas e da história cultural da abolição no Brasil. Neste sentido, podese apontar algumas questôes que, de fato, merecem ser consideradas e contempladas na continuidade do trabalho.

Se considerarmos os resultados apresentados nos últimos tempos pela historiografia dedicada ao estudo do(s) abolicionismo(s), veremos que não há um consenso em torno do caráter radical do abolicionismo defendido pelos membros da Confederação. Diante desta controvérsia, o livro de Eduardo Silva poderia trazer novas luzes sobre a questão. No entanto, ele parece pecar por uma certa supervalorização do radicalismo presente nas propostas dos protetores dos quilombos abolicionistas.

Não há dúvida de que as ações dos membros da Confederação Abolicionista eram ousadas, assustavam e incomodavam os escravocratas. $\mathrm{E}$ certamente também contribuíram para o desmoronamento da escravidão. Mas, tratando-se de um estudo de história cultural, não há como perder de vista a articulação necessária e fundamental entre as práticas e as representações do grupo em questão. Neste sentido, é preciso situar a constituição de quilombos abolicionistas e o apoio e o acolhimento dos fugitivos com as propostas que acompanhavam e sustentavam tais práticas. Qual o significado da liberdade defendida pelos organizadores e patrocinadores dos quilombos abolicionistas? Entre os documentos transcritos ao final do livro, encontramos (no apêndice F) um relato em que Nabuco, em uma reunião no Quilombo do Leblon, discursa para um grupo de 50 escravos refugiados no local. Ao anunciar que a liberdade não tardava "aconselhou que os futuros libertos procurassem percorrer o caminho da honra e do dever, trabalhando, mostrando-se úteis a si e ao país e tornando-se bons cidadãos." (pp.106-107) Ora, tais conselhos nos remetem para outro 
simbolismo presente nas camélias ou, pelo menos, nos fazem questionar a "radicalidade simbólica" da planta e de seus portadores, idéia insistentemente defendida ao longo do livro. Tomando as palavras do próprio autor, veremos que no Brasil daquela época, a camélia era uma planta rara que havia chegado ao Rio de Janeiro por volta de 60 anos antes, ou menos. Não era "uma flor dessas comuns, naturais da terra e encontradiças soltas na natureza. Era, pelo contrário, uma flor em processo de adaptação, uma flor delicada, estrangeira, cheia de melindres com o sol dos trópicos. Uma flor que requeria ambiente mais civilizado [...]"1 (p. 14) Diante deste significado, o que parece mais adequado afirmar é que a liberdade precisava ser cultivada com muito cuidado.

Nestes quilombos abolicionistas, os fugitivos deveriam ser preparados para a liberdade, ouvindo conselhos como os de Nabuco, plantando flores e aprendendo com intelectuais, políticos, jornalistas e comerciantes como desfrutar de sua nova condição. Assim, da mesma forma como aprendiam a cultivar a planta, aprendiam a cultivar sua liberdade de acordo com seus "novos líderes”. Sua liberdade era "camélia", entendida aqui como um adjetivo. É preciso ainda considerar que a flor, provavelmente, expressava a busca por um processo pacífico. Neste aspecto, uma questão interessante, mas não explorada no livro, está ligada a percepção de um ministro norte-americano que acompanhou a tramitação e aprovação da Lei do Ventre Livre, em 1871. O político, na ocasião, ao apanhar uma flor entre as diversas que eram festivamente jogadas aos senadores, teria prometido levar a planta a Washington para que todos pudessem saber que no Brasil se resolvia com flores o que na América do Norte era obtido pelo sangue - uma solução efetivamente radical. A preferência, entre os abolicionistas, por camélias de cor branca também pode ajudar a compor o quadro do abolicionismo expresso por tais flores: a busca por uma solução pacífica, moderada em seus fins e conduzida de forma previdente.

Outra questão que merece aprofundamento diz respeito ao significado da flor entre os escravos. Sabe-se que nas sociedades africanas prevalece a ausência de uma cultura de flores como elementos de ornamentação e uso em geral. O ato de cortálas é visto como algo predatório, uma vez que as mesmas são entendidas como portadoras de uma fase 
preliminar da fruta ou da árvore. $\mathrm{Ou}$ seja, flores colhidas representam uma espécie de aborto e são pouco valorizadas como símbolos. No Brasil, graças ao brilhante estudo de Robert Slenes, sabemos que viajantes estrangeiros repugnavam a ausência de flores nas senzalas, interpretando-a como falta de esperanças e recordações. Tais olhares eram marcados pelos parâmetros da sociedade francesa do século XIX, onde prevalecia um verdadeiro culto ao uso prático e simbólico das flores. Desconstruindo esta visão etnocêntrica, Slenes nos revela que a "flor" das senzalas reluzia nas chamas do fogo sempre presente nos lares escravos e carregado de significados desconhecidos pelos brancos.

Tais reflexões nos conduzem a novas problematizações necessárias a uma investigação de História Cultural. Assim, pode-se interrogar uma questão fundamental, infelizmente não explorada por Eduardo Silva: qual teria sido o significado das camélias entre os escravos? A ausência de uma tradição simbólica em torno das flores entre os africanos torna ainda mais instigante o seu uso pelos escravos na busca de um espaço de liberdade. Como teria ocorrido a construção de um significado em torno das camélias entre os es- cravos? Seria ele o mesmo sustentado pelos intelectuais que comandavam os quilombos abolicionistas? Tais significados teriam sido apropriados e ressignificados pelos fugitivos? Em que medida a liberdade que os fugitivos almejavam se aproximava das expectativas de liberdade pensadas pelos seus "protetores"? Infelizmente, Eduardo Silva limita-se a afirmar que a flor também era usada pelos escravos fugidos com o intuito de serem encontrados pelos abolicionistas nas estações de trem em que desembarcavam ( $\mathrm{p}$. 43). Declara que o simbolismo das camélias perpassava "de uma ponta a outra a sociedade imperial", permitindo-nos "entrever, por detrás dos panos, momentos-chave da história brasileira", com destaque para "a contribuição da princesa imperial, a contribuição fundamental da elite negra e do próprio escravo". Mas em diversas passagens a contribuição dos escravos aparece apenas em sua adesão por meio de fugas em massa, sem a qual, "o projeto abolicionista não teria a mínima chance de êxito" (p. 33).

Sem dúvida, o ato de fugir configurava importante expressão de rompimento que abalava os alicerces do escravismo. Entretanto, ficamos com a impressão de que, após 
esta atitude guerreira de rompimento, os escravos silenciavam-se como aprendizes de uma liberdade "camélia” (ou seria Amélia?). Não traziam consigo uma expectativa de liberdade com uma compreensão própria e distinta daquela "cultivada" por Seixas e outros chefes de quilombos abolicionistas? Provavelmente, mesmo considerando a existência de hierarquias dentro dos quilombosrompimento - já amplamente explorados pela historiografia brasileira -, a relação dos refugiados com seus "comandantes" em quilombos como o do Leblon era diferenciada. Este ponto precisa ser mais bem investigado, assim como as motivações que levavam alguns escravos a optar por quilombos abolicionistas e não por quilombos-rompimento. Estes, obviamente, não deixaram de existir quando da emergência daqueles, nos momentos que antecederam a abolição. Talvez fossem momentaneamente preteridos, por alguns escravos, em função da maior facilidade de acesso ao quilombo abolicionista.

Outra questão importante a ser aprofundada - e que ajuda a recompor as expectativas e motivações daqueles que fugiam para quilombos abolicionistas - diz respeito à rotina dos mesmos dentro de tais es- paços, suas atividades e o tempo que lá permaneciam. Se observarmos o depoimento de André Rebouças (transcrito integralmente no anexo E), dedicado sugestivamente aos "futuros historiadores da abolição", veremos um elenco de oito quilombos abolicionistas situados nos arredores da Corte e, segundo Rebouças, dignos de menção por serem os mais notáveis. O que se percebe é o predomínio da casa de abolicionistas e mesmo as redações de jornais sendo batizadas de quilombos. O próprio palácio de Petrópolis, ao tornar-se esconderijo de escravos nos momentos finais de sobrevivência do sistema escravista, passou a ser denominado, entre os abolicionistas, Quilombo Isabel.

Isto nos faz pensar no caráter provisório e limitado de tais abrigos. Não somente por questôes numéricas inerentes ao espaço disponível, mas principalmente pelo fato de que, nestes locais - diferente do que poderia ocorrer em quilombos-rompimento - os fugitivos obviamente não podiam dispor de liberdade para o estabelecimento de uma vida minimamente autônoma. Sem negar a importância dos mesmos, como mais um entre os diversos recursos eficientes empregados nas lutas pela abolição, pode-se conjecturar que, 
aos olhos dos escravos, tais espaços constituíam territórios-ponte para uma liberdade carregada de significados próprios, permeada de autonomia e mobilidade. Um refúgio provisório do qual poderiam partir para outra província em busca de parentes e amigos, para um quilombo-rompimento ou mesmo para a região da chamada África Pequena, no Rio de Janeiro, onde poderiam "plantar outras flores" com outros significados, com outros perfumes... Flores não abortadas que poderiam cumprir integralmente seu papel, dando aos seus cultivadores os frutos esperados.

\section{Nota}

${ }^{1} \mathrm{O}$ grifo é nosso. 